\title{
The circular and linear structure of political values and the three stereotypes about the left, center and right
}

\begin{abstract}
The aim of the article is to give arguments against the presence of three stereotypes in political science concerning leftism, centrism and rightism. The first one involves the classification of political entities by indicating their place on the left-centre-right axis. The second is based on the belief that leftism, centrism and rightism can be narrowed down to specific levels of competition (e.g. views on the economy or religion). The third stereotype is "dogma" that the conflict over political values was initiated during the French Revolution. The author explains his position with reference to the psychological theory of Shalom H. Schwartz and the circular matrix of meta-value.
\end{abstract}

Key words: circular matrix of meta-values, left; centre, right, political values

$\mathbf{T}$ he values present in public sphere have a simultaneously circular and linear structure. Explaining these correlations is key to understanding the left, center and right in politics. In the first part of the article, the concept of Schwartz's basic values and the circular model of meta-values created on this basis is presented. In the following part, a critique of stereotypes concerning the left, center and right is discussed.

\section{The Schwartz theory of basic values}

Shalom H. Schwartz is a social psychologist whose research since the 1970s has focused on values. Based on the results of empirical studies, he formulated the theory of basic human values, which presented the universal structure of human values and the mechanism of axiom selection by individuals (Schwartz, 1992).

The first component of this concept was to define the meaning of human values. The author described them as: (1) beliefs intrinsically related to emotion that, when activated, generate positive and negative feelings; (2) a motivational construct that drives people to act in an appropriate manner; (3) something that transcends specific situations and actions, differing from social attitudes and norms, in addition to guiding people in various social contexts; (4) something that guides the selection and evaluation of actions, policies, people and events and that composes criteria for judgements; (5) something that is ordered according to the relative importance given to the other values, and, thus, forms an ordered system of axiological priorities (Torres et al., 2016, p. 342).

The second component was to establish that the basic human values system is universal and takes the form of a circular motivational continuum. Graphically, it can be represented in the form of a circle, in which the axioms are selected based on the rules of compliance and conflict. In Figure 1 Rules of the Shalom H. Schwartz model, the letters 
symbolize different types of values, each of which can be assigned opposite values. The extremes form a continuum with values gradually less and less similar to their opposites, and increasingly resembling those nearby. Axioms can be arranged side by side in such a way that value $A$ is similar to value $B$, which value $F$ resembles, but which is less similar to value A. Additionally, more detailed values are located between the axioms A, B and F - forming a continuum. Values located opposite each other (e.g. A and K) cannot be realized at the same time, because they lead to conflicting goals.

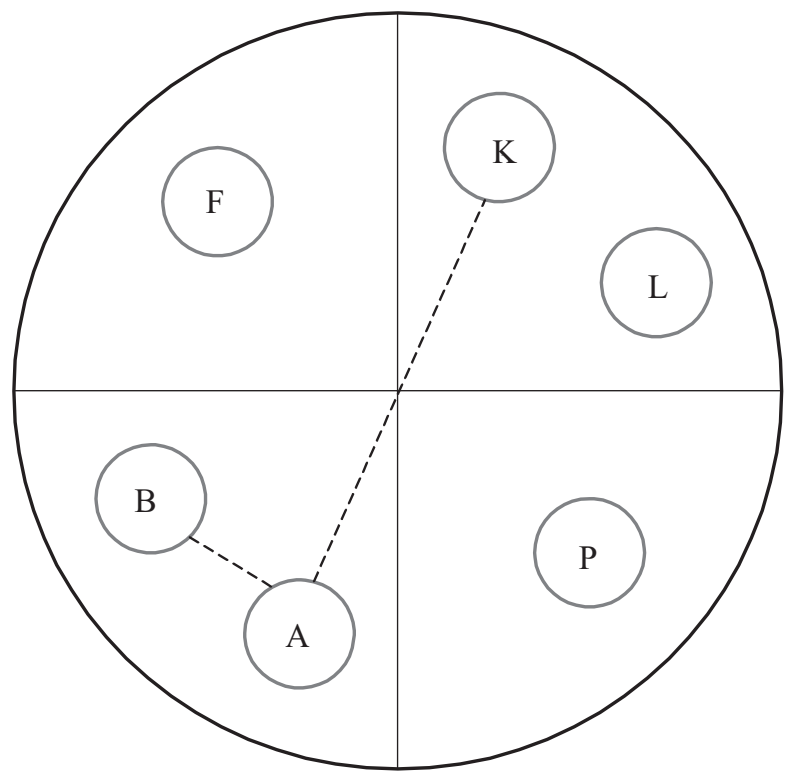

Figure 1. Rules of the Shalom H. Schwartz model

(Cieciuch, 2013, p. 46).

The distribution of values in Schwartz's model has been refined since the late 1980s. The classic and most popular version including ten axioms was modified in 2012 by dividing the basic values into more detailed ones - as illustrated in Figure 2.

The set of values includes (Cieciuch, Schwartz, 2017, p. 3):

- self-direction - covering such values as self-direction-thought (freedom to cultivate one's own ideas and abilities) and self-direction-action (freedom to determine one's own actions);

- stimulation - excitement, novelty and challenges in life;

- hedonism - pleasure or sensuous gratification for oneself;

- achievement - personal success through demonstrating competence according to social standards;

- power - comprising power-dominance (power through exercising control over people) and power-resources (power through control of material and social resources);

- security - including security-personal (understood as safety in one's immediate environment) and security-societal (safety and stability of society);

- face - protecting one's public image and avoiding humiliation; 
- conformity - divided into two more specific values: conformity-rules (compliance with norms, rules and obligations) and conformity-interpersonal (restraint of actions, inclinations, and impulses likely to upset or harm others);

- tradition - accepting customs and cultivating traditions and ideas that one's own culture, religion or family provides;

- humility - recognizing one's insignificance in the larger scheme of things;

- benevolence - divided into benevolence-dependability (being a reliable and trustworthy member of the group) and benevolence-caring (ability to sacrifice, care for the well-being of other group members);

- universalism - within which three specific values were distinguished: universalismconcern (commitment to equality, justice and the well-being of all people), universalism-nature (environmental protection) and universalism-tolerance (acceptance and understanding for those who are different from oneself).

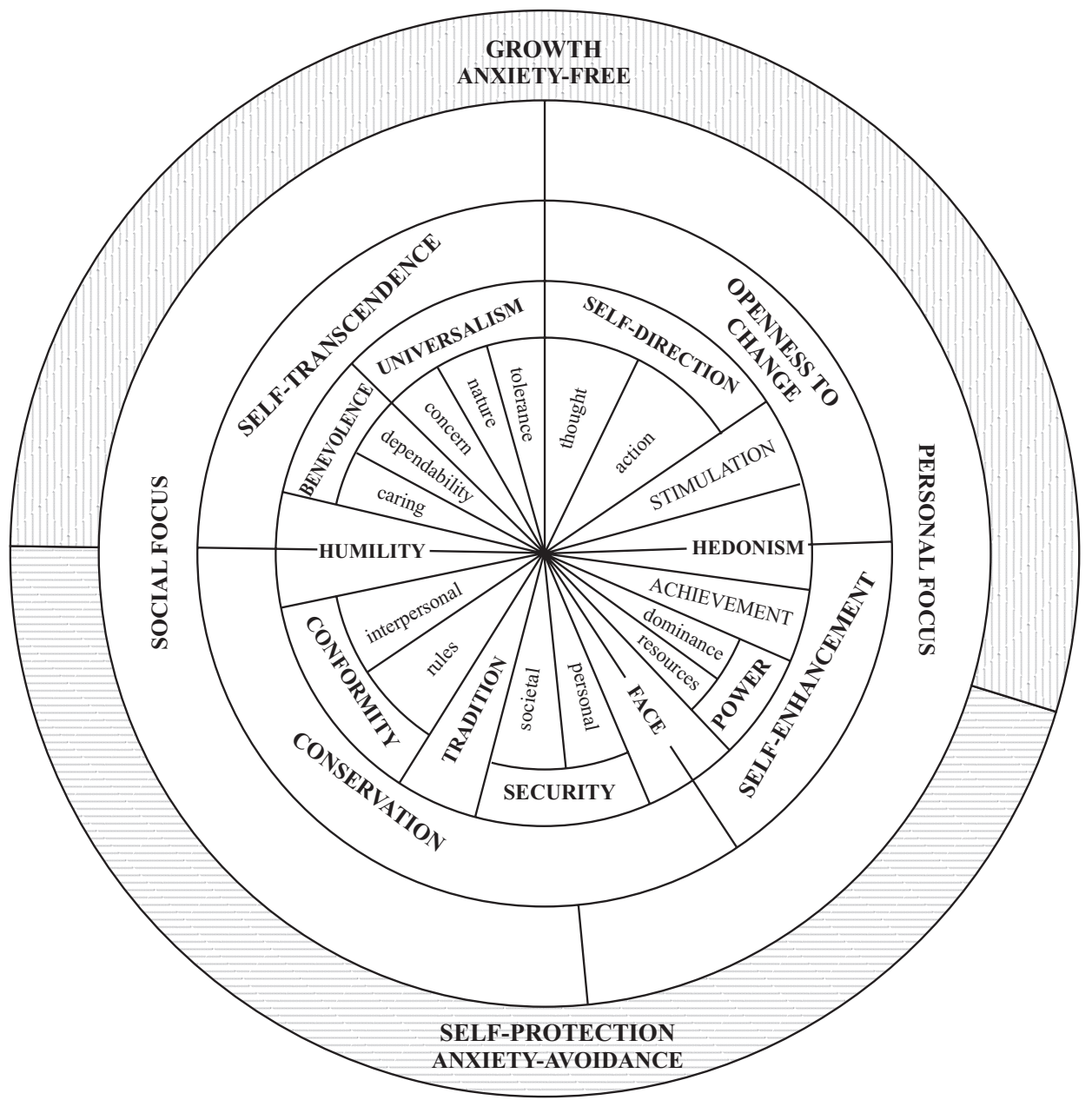

Figure 2. Circular structure of the human values by Shalom H. Schwartz (on the basis of Schwartz et al., 2012, p. 669). 
The discrete values were arranged into four main types: (1) self-transcendence, cocreated by universalism and benevolence; (2) self-enhancement, consisting of power and achievement; (3) openness to change, in which Schwartz included self-direction and stimulation, and (4) conservation, consisting of conformity, tradition and security. Hedonism, humility and face are border values that are a part of neighboring groups of values.

In the Schwartz model, the hierarchy of human values is circular in nature and results from giving priority to axioms located near the highest-rated value (Cieciuch, Schwartz, 2017, pp. 2-3), e.g. an individual with conservative views may have a hierarchy of tradition $>$ power $>$ security $>$ conformity. In this case, tradition is the highest-rated value, and the compliance rule causes a person to opt for axioms that are nearby.

According to the conflict rule, distant axioms will be rated as inferior. In the circular model, tradition and stimulation are located at a considerable distance from each other. Therefore, stimulation is perceived as inferior in the case of a "conservative." Moreover, opposition of these two values is apparent, as the desire to consolidate tradition is at odds with the need for novelty and change.

\section{Circular and linear structure of political values}

Values that are present in the public sphere (in party platforms, political debates, declarations, and decisions) will be referred to as meta-values. These types of axioms can be characterized as follows:

1. The meta-values are abstract; therefore, they cannot be reduced into another type of value. Examples of such axioms are liberty, equality, authority, progressivism, religion or tradition;

2. Meta-values are motivational goals that guide the community (society). In a democracy, we indicate these goals by casting our vote for entities declaring support for certain types of values. Democracy is the only system that gives citizens the opportunity to choose the axioms that will be considered in the decision-making processes;

3. Meta-values are political axioms developed within a particular society (Maj, 2018, pp. 143-146). They can be arranged within the four main types distinguished by Schwartz (self-enhancement/self-transcendence and conservation/openness to change) in accordance with the rules of compliance and conflict;

4. Policy proposals are developed based on meta-values, e.g. the idea of progressive tax was constructed on the basis of the left-wing meta-value of equality. In turn, the concept of participatory budgeting is derived from the meta-value of self-governance. Projects to tighten migration policy are intended to defend the right-wing meta-values of community and tradition. The policy proposals are derived from one or more meta-values;

5. Axiological conflicts in democracy result from antinomy of meta-values. During the French Revolution these values were given the labels of "left-wing" and "rightwing." The sources of these conflicts lie in the contradictory sets of basic values described by Schwartz;

6. Meta-values are essential for an individual, since they may support or prevent the implementation of basic values. If political power is gained by the Christian Democratic party and at the state level high priority is given to the religion meta-value (one of whose 
assumptions is the presence of faith in the public sphere), this will not be acceptable to a person who prioritizes basic values within the 'openness to change' range (giving preference to religion in the public sphere violates their personal hierarchy of values).

With respect to the model proposed below, two observations should be made. First of all, the matrix of meta-values is valid only in the analysis of political systems meeting the procedural criteria of democracy. In totalitarian and authoritarian systems, citizens are deprived of the right to indicate their preferred axioms. Thus, the analysis of ideologies in non-democratic systems as "leftist," "centrist" or "right-wing" is not possible. Secondly, these values differ across various civilizations (Routamaa, Brandt, 2008). The circular model of right-wing and left-wing meta-values is a proposal to define this type of axiom in Western societies (within the boundaries set by Samuel P. Huntington (1996)).

According to Figure 3 Circular Structure of Meta-Values, the "north' side of the model is intended for left-wing axioms. The left is determined by seven meta-values: equality, society, individual liberty, self-governance, plurality of value systems, progressivism and rationalism. The names distinguished are contractual, while their meaning is crucial, setting political motivational goals at the state level. The basic meaning of these meta-values is as follows:

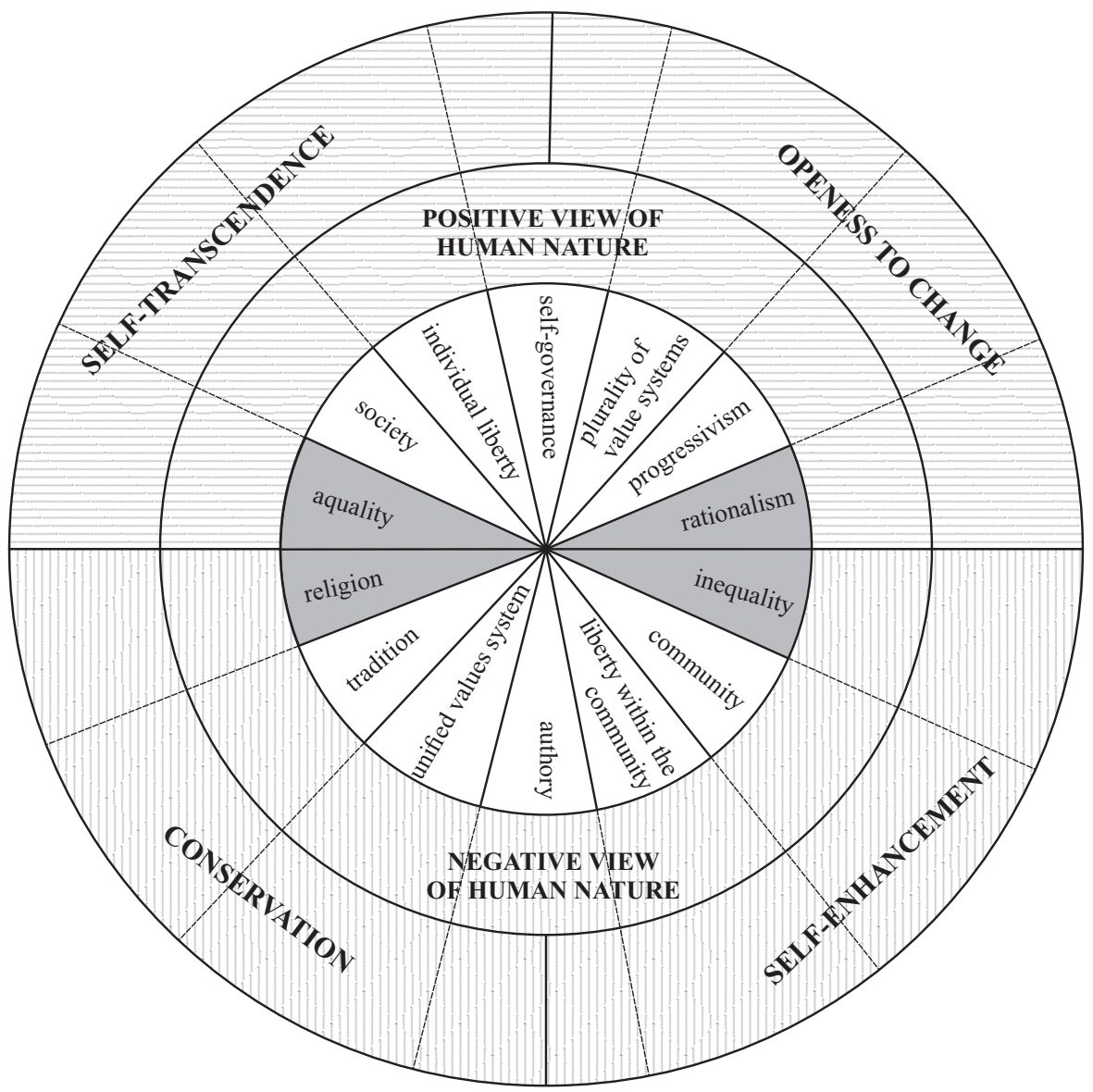

Figure 3. Circular structure of the meta-values (Maj, 2018, p. 148) 
The axiom of equality, with its economic, political and social dimension, becomes a foundation of social programs and proposals for limiting various privileges. This is justified by the principle of justice, which has a social and distributive meaning, and is anchored in the group of self-transcendence values and oriented towards others (the weak, the disadvantaged).

Universalism and going beyond state boundaries are characteristic to society. This vision assumes equal and free individuals who are socially and politically active. Belonging to society is subjective (the decisive factor is the subject's sense of belonging). Meeting formal requirements permits an individual to become an equal member of a society (e.g. by obtaining citizenship). This is irrespective of beliefs, language, faith or other attributes. Citizens should show social activity and act for the welfare of others. They should be involved in politics, because high voter turnout is a measure of the quality of democracy.

Individual liberty has the broadest possible context; citizens enjoy an extensive cata$\log$ of rights, including those relating to personal choices and decision-making. Restrictions of individual liberty are imposed in accordance with Kant's categorical imperative. The aforementioned rule was formulated based on philosophical attempts to establish universal ethical principles defining individual conduct without reference to religion. In simple terms, its content is as follows: we should respect such standards that we would like to be applied to anyone and at any time (Singer, 1954).

Self-governance refers to the democratization of hierarchical structures. The state exists for citizens and reflects their wishes. It is desirable that decisions are made directly by the governed, or at the lowest possible representative levels. Decentralization facilitates an increase in the subjectivity of society members. Policy making at low decisionmaking levels forces consideration of various arguments and points of view and leads to consensual solutions.

Plurality of value systems is the desire to have a world free from top-down moral commands or authorities. Practically, it refutes the pursuit of a hegemonic value system in politics. Defining morality according to a single axiological system seems impossible, since interpretations of basic axioms are subjective (e.g. several dozen definitions of good can be found in ethics). Therefore, plurality of value systems is a state in which many different value systems operate freely in the public sphere, and state institutions recognize them as equal, not favoring or discriminating against any of them.

The meta-value of progressivism is rooted in the belief in inevitable development, civilization, and technological and economic progress. Progressivism strives to "liberate man from the embarrassing corset of traditions, customs and imposed obligations and, as a result, to expand the area of individual freedom" (Reykowski, 2011, p. 47). Parting with tradition is not an endeavor in itself, because it is mainly the aspect of tradition that blocks social change and the possibility of human self-improvement that is rejected.

Rationalism is the pursuit of secularization of not only state institutions, but the public sphere in general. It is based on the assumption that there are no supernatural events or processes, and reality can only be explained by scientific knowledge; religion is a private matter and as such should not interfere with public sphere in any way. Rationalism is based on models of relations between the state and the Church which introduce institutional separation and, from the perspective of state power, ensure axiological sovereignty. 
The 'southern' side of the model includes such domains as: "self-enhancement" and "conservation," and in politics is utilized by right-wing ideas of inequality, community, liberty within the community, authority, unified value system, tradition and religion.

Inequality assumes that the differences between people are natural and result from individual characteristics and one's social competences and position. People are considered unique, and differentiation is a prerequisite for individual and social development. This results in a hierarchical view of society, considered natural and desirable. Inequality is considered to be just (as in the case of equality). However, its meaning is completely different. Right-wing justice has a natural origin (Scruton, 2002, p. 102) and is interpreted within the group of values of "self-enhancement." State institutions should not interfere in differences between individuals, which concerns not only economic but also social status. Left-wing equality is perceived as imposing a monolithic vision of society.

Community is understood as a historically-shaped cultural and/or ethnic group (nation). Organicism and anti-egalitarianism (elitism) are the keys to its interpretation. The basis of organicism is the recognition that individuals are not self-sufficient and independent of the community, and therefore self-realization is only possible through participation in a larger whole. Anti-egalitarianism is in line with the right-wing idea of social order derived from tradition or religion. The goals of community are opposed to the liberal concept of the autonomy of the individual presented in the meta-value of society.

Liberty within the community is not absolute, and is limited by the participation of an individual in a group. The community determines the scope of liberty, creating moral norms regulating its members' conduct. The starting point is the negative view of human nature, on the basis of which certain restrictions are imposed on the individual. These restrictions can be relaxed only if it is certain that this will not result in social disorder (Wendelken, 1996).

The meta-value of authority is based on a centralized vision of human relations. $A u$ thority is not (as in the case of the left) a means to implement the principle of equality and social justice, but "serves to command and influence" (Scruton, 2002, p. 37). The state authority should be strong and effective. The processes of decentralization and delegation of powers are negatively perceived because they result in the restriction of authority, blurring responsibility for decision-making and reducing the effectiveness of the state. From the meta-value of authority stems the idea of depoliticizing society - politics should not be dealt with by all those entitled to vote, but by those in power. This is supposed to reduce social conflicts, the source of which is the difference in philosophy, moral systems and ideologies.

The right strives for a unified values system. It is assumed that the existence of a common axiological denominator is beneficial for the community (nation). Therefore, in the public sphere, axioms constructed through historical experience, considered characteristic for the given community, are highly valued. One specific axiological system is clearly indicated, and competing ones are treated as a potential threat to the continuity of the community. Values are passed down through generations through tradition, experience and with the participation of authorities.

In Western civilization, the meta-value of religion covers various variants of Christianity. Religion is an element of the natural order, a source of hierarchy of values, including in the public sphere. It is assumed that the leftist idea of the ideological neutrality 
of the state is purely theoretical and does not exist in reality, because those exercising power always represent a specific system of values. From the moral perspective, the system should be anchored in the religion of a given community. The right attempts to preserve the presence of religion in both the private and public spheres. This tendency manifests in the postulate of strengthening the institution of the Church, which means financial support from the state, declaring attachment to the system of values inspired by the religion of the community, referring to moral norms, and criteria for assessing fairness, truth and falsehood through the prism of religion.

Tradition is understood as attachment to the natural order, heritage and care for the historical memory of the community; two varieties are distinguished (Reedy, 1981). The first, inspired by Edmund Burke's views, is based on a philosophy of change as similar as possible to the previous state and leads to continuity. The second, in line with Louis de Bonald's (or Joseph de Maistre's) ideas, aims at restoring an order considered natural and eternal, which sometimes requires a change in the current state (restitution, restoration). The common denominator of these two meanings of tradition is continuity, understood as maintaining the principles that determine human behavior and the identity of the community.

The conflict rule in the matrix leads to the distinction of seven pairs of values and their opposites. These are the following dichotomies: equality-inequality, society-community, individual liberty-liberty within the community, self-governance-authority, plurality of value systems-unified values system, rationalism-religion and progressivism-tradition.

The compliance rule, on the other hand, means that neighboring values are close to each other. E.g. tradition - a right-wing value - is close to unified values system and religion. In turn, authority is more similar to community than equality, which lies in the 'northern' part. The matrix has the character of a circular continuum - the more distant the meta-values are, the greater the differences between them.

On the border of the 'northern' and 'southern' part of the model, tangential metavalues can be found. These are axioms belonging to different types, but which are at the same time similar to each other. In the 'eastern' part, these types of values are rationalism and inequality, and in the 'western' part religion and equality. In politics, the axioms of the tangential areas are borrowed by entities self-identifying with both the left and the right. They form an axiological buffer separating two types of worldviews - left-wing, constructed within the types of "self-transcendence" and "openness to change," and right-wing, shaped within the types of "self-enhancement" and "conservation."

In the 'eastern' part of the model, tangential values are rationalism and inequality. From a 'northern' perspective, this is the place where left-wing meta-values come into contact with right-wing inequality. Classical liberalism has been built on this set of values (society, individual liberty, plurality of value systems, self-governance, progressivism, rationalism, inequality).

In the 'western' part of the matrix, at the junction of two types of values, there is a space where right-wing meta-values meet left-wing equality. Looking from the southern perspective, these are the axioms to which Christian democracy refers (community, liberty within the community, authority, unified values system, tradition, reli- 
gion, equality). The relations concerning tangential values are symmetrical - one can point to the 'northern' inspirations of the religion which appeared in the liberation theology, as well as to the 'southern' references to rationalism, a characteristic of the secular right.

Another element of the matrix is the antinomical views of human nature (the concept of man) that function in politics and philosophy. From the perspective of the model, they are intended to justify preferences towards the 'northern' (left-wing) or 'southern' (right-wing) meta-values. Note that the 'concept of man' is always a model, and not a full empirical description of human nature. Only those elements that allow justification are emphasized. For example, in liberal concepts, tradition and culture are usually overlooked, which results from the goal of emphasizing the causative abilities of the individual and their autonomy in shaping their own environment.

In the case of the left, positive qualities are emphasized, while in the case of the right, negative qualities come to the fore. The starting point in a positive concept is the belief that humans are good by nature. If an individual behaves badly, the causes are looked for in his/her environment (they are exogenous to him/her). They are external barriers that prevent individuals from improving themselves. Such restrictions include poverty, lack of access to education, or discrimination. The left's solution for lifting these barriers is the implementation of policies promoting equality, society, individual liberty, self-governance, plurality of value systems, progressivism and rationalism at state level.

The right emphasizes a negative view of human nature. This is based on the conviction that humans can be intrinsically good or evil, and that this is endogenous in nature and can manifest itself when an individual consciously chooses to behave a certain way. The source of evil in the world is not, as in the case of the positive view of human nature, factors that are independent of human beings - the choice depends solely on the person concerned. Because human nature is imperfect and unchangeable, certain restrictions should be imposed on individuals, which can be reduced in certain situations. The way to overcome human weaknesses is to act in accordance with a system of rules that define behavior in various situations. These are religious, moral and legal norms.

The distinguished 'northern' and 'southern' meta-values have a circular structure, and form a linear continuum when analyzed in antinomical pairs. This allows us to identify centrist values, which are constructed in reference to seven pairs of meta-values. Centrist axioms are intended to decrease the political conflicts arising from the antinomy of the value system. They always have a derivative character and often take the form of a compromise.

Take the example of equality-inequality pair. The left justify equality with social justice and humanism. From the right-wing perspective, inequality is justified by tradition and has a natural origin. When analyzing the pair of equality-inequality in the context of social policy, the leftist pursuit of equality manifests itself in the welfare state, and the right-wing acceptance of inequality is reflected in the concept of a night-watchman state, while the centrist compromise is found in the idea of the activating state (Dingeldey, 2007). In the last instance, the possibility of using social programs depends on a certain level of initiative from those concerned (see Fig. 4 Linear continuum of political values). Linearity is a feature of the remaining six pairs of meta-values, which allows centrist values to be extracted. 


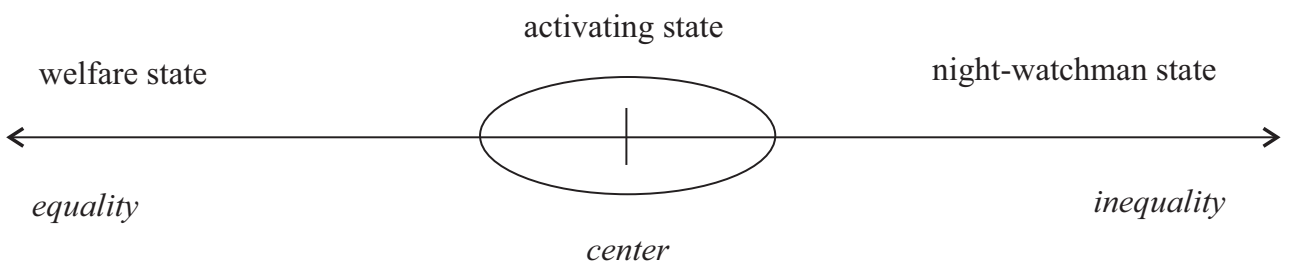

Figure 4. Linear continuum of political values

\section{The meta-value matrix and three stereotypes regarding the left, center and right}

The first stereotype is to think about political values in subjective terms. For instance, we try to classify political parties by indicating their place on the left-center-right axis. An example of this would be the statement that "the Greens/EFA group in the European Parliament is on the left" or "the German CDU is on the right." Meanwhile, assigning a political party to the left, center or right is a similar procedure to trying to categorize people into "good" and "bad." By assigning a subject into one of three categories, we do not allow for the possibility of evolution by "locking it" into one of these groups. In political practice, some subjects are ideologically variable. Others (like Christian Democracy) refer to tangential values. Assigning a party to a place on the left-center-right axis will always be debateable and subjective.

The basic postulate is to shift analysis to the level of values. The left, center and right should be treated as systems derived from the basic values of the Schwartz model. The use of the terms "left," "centee" and "right" should be limited to abstract situations, as labels for value systems.

The second stereotype is the belief that the left, center and right can be narrowed down to certain levels of competition (e.g. views on the economy or religion). Actually, they cannot be reduced to one or even several dimensions of rivalry. With the passage of time and social, economic and technological progress, the levels of analysis of the three are constantly expanding, because conflicts over meta-values are automatically transferred to new dimensions. Therefore, political divisions emphasize competition between the three options rather than blur the differences between them. Let us look at the scheme in which new dimensions are being politicized.

During the French Revolution, competition concerned axiological and constitutional issues. Debate focused primarily on the scope of royal authority, the scale of changes within society (associated with equal rights, broadening the scope of freedom), the presence of religion in the public sphere and attitudes towards the past. On the meta-value level, it was the conflict between the authority-self-governance, religion-rationalism, inequality-equality and tradition-progressivism pairs.

During the Industrial Revolution, the socioeconomic dimension was politicized. The conflict between owners and workers concerned the equality-inequality pair and was conducted by liberal and workers' parties. A side effect of industrialization, in turn, was the politicization of environmental protection issues. The dispute in this sphere is multi-valued and continues to this day. It involves the pairs of equality-inequality, self- 
governance-authority, progressivism-tradition, and rationalism-religion, belonging to all four main types. The expansion of the Internet in the 1990s led to the creation of another dimension of conflict - cyberspace. As in previous cases, political actors "used" this sphere, extending the dispute about meta-values. As early as 2000, American Democrats offered free access to the Internet under the slogan of reducing digital divide, and Republicans offered access to a network "devoid of pornography and family friendly" (Klotz, 2004, p. 91), claiming to defend traditional values. Attitudes to cyberspace were a derivative of accepted meta-values: in the case of Democrats - equality and individual liberty, and for Republicans - of a unified values system and tradition.

As can be noticed, meta-values are present in all areas of political competition - they are multidimensional. Political demands in particular dimensions are defined in relation to the supported types of values. This is tantamount to politicizing these dimensions (and generating new conflicts).

The third stereotype is the 'dogma' that the conflict over meta-values initiated during the French Revolution. However, the analyzed pairs of values are not a product of the turn of the eighteenth and nineteenth centuries, because they date back to the beginnings of Western civilization. They were formed under the influence of events of key importance to civilization, such as the emergence of Roman law, Greek democracy and Christianity.

In period immediately prior to the French Revolution, disputes about meta-values were fought by various entities, which can be described as archetypes of the left and right. Analysis of the history of Western civilization reveals that these archetypes emerged when decentralization of state power occurred. As examples, we can give the "aristocrats" and "democrats" in the Greek polis, the Optimates and Populares in Rome, and the Tories and Whigs in 17th-century England.

In Greece, the dispute concerned systemic issues and the vision of society. "Aristocrats" criticized democracy, linking it to the disintegration of traditional moral norms and social order. They were a part of the Areopagus (which, before the reforms, was the institution that controlled politics) and defended its powers, as well as the traditional social hierarchy. "Democrats" worked to promote egalitarianism, and also to reduce the influence of the aristocracy and the importance of the Areopagus.

In Rome, the archetype of the right were the Optimates who, like the Greek "aristocrats," defended the traditional hierarchy and stood up against attempts to change the system. Their opponents were the Populares who represented the interests of the commoners, advocating reforms and criticizing the Senate. The Populares in Rome, as with the "democrats" in Athens, were in favor of giving rights to the people deprived of them.

In England, the archetypes of the left and right were the Whigs and Tories. The conflict between these parties dates back to the 17th century. The dispute between Tories and Whigs was multidimensional, covering systemic, social, economic and religious issues. The former defended the interests of the gentry and the monarch's power, striving to maintain the traditional social structure, including existing inequalities and privileges. The Whigs sought to increase parliamentary power at the expense of the monarch's authority. The differences between the factions were also pronounced in the sphere of religious views - the Whigs advocated the rights of nonconformist Protestants, while the Tories supported the Anglican Church. 
To sum up, the subject of conflicts between the distinguished archetypes were always the same pairs of meta-values: progressivism-tradition, as a dichotomy that defines views not only in the matter of social changes, but also in the field of morality and customs; equality-inequality, in the context of seeking to abolish or maintain inequalities and privileges; and authority-self-governance, that determines views in relation to the central authority (its strengthening or weakening). The meta-values were the common denominator of the worldview of the presented archetypes of the left and right; they have appeared as a source of conflict in various states throughout the history of Western civilization and, most importantly, existed in the period preceding the French Revolution.

During the French Revolution, the same meta-value pairs again became the cause of divisions - this time between the left, center and right in the National Assembly. During this period, the meta-values were "assigned" the labels of left and right. However, as Norberto Bobbio (1996, p. 33) noted, the tags of 'left' and 'right' were random because, if not for the events in France, they could have been different.

On the image of the circular matrix, we can call these values left-wing and rightwing, but also northern and southern, or blue and red. In turn, Shalom Schwartz (2012) proposed that basic human values covering types of self-transcendence and openness to change should be distinguished as "growth," while those encompassing self-enhancement and conservation should be seen as "self-protection." To sum up: what is described in politics as the left, center and right takes on a new meaning in the context of the circular model, and the labels themselves become secondary - they are one of many possible terms.

\section{Conclusion}

The following conclusions can be formulated:

Firstly, the left, center and right are determined temporally. Understood as value systems, they are not the result of the French Revolution, as they have been in existence since the beginning of Western civilization.

Secondly, the left, center and right cannot be reduced to one or even several dimensions of rivalry. Their characteristic feature is the constant expansion into new dimensions. The levels of analysis of the triad expand with time and social, economic and technological development.

Thirdly, the terms left, center and right as the names of political factions are purely historical ones. Since the French Revolution, there have been changes that make this interpretation inadequate. The basic postulate is to shift from understanding the left, center and right in a subjective way (i.e. classifying parties as left-wing, centrist or right-wing) to understanding these positions through meta-values.

\section{Bibliography}

Bobbio N. (1996), Left and Right. The Significance of a Political Distinction, The University of Chicago Press, Chicago. 
Cieciuch J. (2013), Ksztaltowanie się systemu wartości od dzieciństwa do wczesnej dorostości, Liberi Libri Publishing House.

Cieciuch J., Schwartz S. H. (2017), Values, in: Encyclopedia of Personality and Individual Differences, eds. V. Zeigler-Hill, T. K. Shackelford, Springer International Publishing, Cham, pp. 1-5.

Dingeldey I. (2007), Between workfare and enablement-The different paths to transformation of the welfare state: A comparative analysis of activating labour market policies, "European Journal of Political Research" 46 (6), pp. 823-851.

Downs A. (1957), An Economic Theory of Political Action in a Democracy, "Journal of Political Economy" 65(2), pp. 142-145.

Gallagher M., Laver M., Mair P. (2011), Representative government in modern Europe, McGrawHill.

Harmel R., Svåsand L. (1993), Party leadership and party institutionalisation: Three phases of development, "West European Politics" 16(2), pp. 67-88.

Huntington S. P. (1996), The clash of civilizations and the remaking of world order, Simon and Schuster, New York.

Inglehart R. (2007), Postmaterialist values and the shift from survival to self-expression values. The Oxford handbook of political behavior, Oxford University Press, Oxford.

Kitschelt H. (1992), The formation of party systems in East Central Europe, "Politics \& Society" 20(1), pp. 7-50.

Klotz R. J. (2004), The politics of Internet communication, Rowman \& Littlefield, Lanham.

Lipset S. M., Rokkan S. (1967), Cleavage Structure, Party Systems, and Voter Alignments: An Introduction, in: Party systems and voter alignments: Cross-national perspectives, eds. S. M. Lipset, S. Rokkan, Free Press, New York.

Maj P. (2018), Lewicowość, centrowość i prawicowość w nauce o polityce [Leftism, centrism and rightism in political science] (in Polish), Rzeszów University Press, Rzeszów.

Mudde C. (1999), The single-issue party thesis: Extreme right parties and the immigration issue, "West European Politics" 22(3), pp. 182-197.

Reedy W. J. (1981), Burke and Bonald: Paradigms of Late Eighteenth-Century Conservatism, "Historical Reflections / Réflexions Historiques" 8(2), pp. 69-93.

Reykowski J. ( 2011), Trzecia Rzeczpospolita a lewica, in: Projekt dla Polski. Perspektywa lewicowa, ed. J. Reykowski, Warszawa.

Routamaa V., Brandt T. (2008), Understanding Cultural Differences The Values in a Cross-Cultural Context, "International Review of Business Research Papers" 4(5), pp. 129-137.

Schwartz S. H. (1992), Universals in the Content and Structure of Values: Theoretical Advances and Empirical Tests in 20 Countries, in: Advances in Experimental Social Psychology, ed. M. P. Zanna, New York Academic Press, New York, pp. 1-65.

Schwartz S. H., Cieciuch J., Vecchione M., et al. (2012), Refining the theory of basic individual values, "Journal of personality and social psychology" 103(4), pp. 663.

Scruton R. (2002), Co znaczy konserwatyzm?, Zysk, Poznań.

Singer M. G. (1954), The Categorical Imperative, "The Philosophical Review” 63(4), pp. 577-591.

Torres C. V., Schwartz S. H., Nascimento T. G. (2016), The Refined Theory of Values: associations with behavior and evidences of discriminative and predictive validity, "Psicologia USP" 27(2), pp. 341-356.

Wendelken D. (1996), Contemporary Conservatism, Human Nature, and Identity: The Philosophy of Roger Scruton, "Politics" 16(1), pp. 17-22. 


\section{Kołowa i linearna struktura wartości polititycznych oraz trzy stereotypy dotyczące lewicowości, centrowości i prawicowości}

\section{Streszczenie}

Celem artykułu jest przedstawienie argumentów na rzecz rezygnacji z utrwalania w nauce o polityce trzech stereotypów dotyczących lewicowości, centrowości i prawicowości. Pierwszy z nich polega na klasyfikowaniu podmiotów politycznych przez wskazywanie na ich miejsce na osi lewica-centrumprawica. Podstawą drugiego jest przekonanie, że lewicowość, centrowość i prawicowość można zawęzić do określonych płaszczyzn rywalizacji (na przykład do poglądów na gospodarkę, kształt państwa, religię). Trzecim stereotypem jest „dogmat”, że konflikt o wartości polityczne został zapoczątkowany w okresie rewolucji francuskiej. Autor uzasadnia swoje stanowisko w odniesieniu do psychologicznej teorii Shaloma H. Schwartza oraz kołowej struktury wartości politycznych.

Słowa kluczowe: kołowa macierz metawartości, lewica, centrum, prawica, wartości polityczne 